\title{
A PROBIOTIKUMOK MÚLTJA, JELENE ÉS JÖVÔJE
}

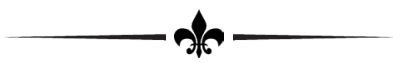

\section{THE PAST, PRESENT AND FUTURE OF PROBIOTICS}

\author{
$-2$ \\ 1,2 PAPP-BATA, ÁGNES \\ ${ }^{1}$ SZAKÁLY, Zoltán \\ $-10$ \\ ${ }^{1}$ Debreceni Egyetem, Gazdaságtudományi Kar, Marketing és Kereskedelem Intézet \\ (Institute of Marketing and Commerce, Faculty of Economics and Business, University of Debrecen) \\ H-4032 Debrecen, Böszörményi út 138 . \\ e-mail: dr.pappagi@gmail.com \\ ${ }^{2}$ Debreceni Egyetem, Ihrig Károly Gazdálkodás- és Szervezéstudományok Doktori Iskola \\ (Károly Ihrig Doctoral School of Management and Business, University of Debrecen) \\ H-4032 Debrecen, Böszörményi út 138 .
}

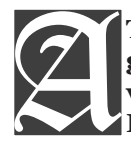

The scientifically proven relationship between diet and health along with the continuously growing health consciousness of customers resulted in a fundamental change in social values and led to a pronounced demand for foods that support health and wellness. Probiotic products, especially dairy products containing active cultures represent a strongly growing area within the functional foods market. Although mankind recognized the importance of fermented dairy products in a healthy diet thousands of years ago, scientifically based modern methods of altering the bacterial composition of the gut flora have only evolved in recent decades. The reinforcement of commensal microflora with probiotics plays a key role in the balanced immune functions, increases the resistance against pathogens, improves the functions of digestive system and potentially facilitates the removal of carcinogens from the intestinal system. Consumer demand for probiotic products is growing strongly; while their global sales in 2010 were $\$ 21.6$ billion, it rose to $\$ 49.4$ billion by 2018 . Nowadays, probiotic yoghurts account for $75 \%$ of global probiotic trade, other probiotic food products accounts for $16 \%$ and probiotic drugs accounts for $9 \%$. However, based on current trends, the role of pharmaceutical products will gradually increase in the future, presumably at the expense of traditional probiotic dairy products. Furthermore, given that the elderly population is likely to be one of the most significant consumer groups in the probiotic trade in the Western and Far Eastern markets in the next 10-15 years, it may be necessary to re-design the innovation and product development strategy accordingly. Appropriate marketing strategy and communication also play a key role in ensuring the market success of probiotic dairy products in the future. Reliable and credible information play an important role in developing personal motivations, health-conscious lifestyle and positive consumer attitude toward probiotic food products.

KULCSSZAVAK: probiotikumok, tejtermékek, funkcionális élelmiszerek, élelmiszerfejlesztés, élelmiszermarketing
KEYwORDS: probiotics, dairy products, functional foods, food development, nutrition marketing

JEL-KóDOK (JEL CODES): D83, I10, L66

DOI: https://doi.org/10.34100/TEJGAZDASAGvol78iss1-2pp19-27 


\section{BEVEZETÉS - INTRODUCTION}

A XX. század végére a korábbi évtizedek robbanásszerű technikai fejlődése és társadalmi változásainak következtében előbb a fejlett iparosodott államokban, majd később világszerte drasztikus emelkedésnek indult az életmóddal és táplálkozással összefüggő betegségek gyakorisága, mely egyre súlyosbodó teherként jelent meg egyéni, társadalmi és gazdasági szinten egyaránt (MENDIS et al., 2011). Azonban az intenzív élettani és orvostudományi kutatások rávilágítottak a megfelelő táplálkozás preventív jellege mellett annak hatékony terápiás intervenciós szerepére is az elhízás, hipertónia, cukorbetegség, szív- és érrendszeri betegségek, emésztőszervi betegségek, illetve rosszindulatú kórképek esetében. Mindezek következtében a fejlett országok lakosságának egyre szélesebb köreiben tudatosul, hogy egészségtudatos táplálkozással és életmóddal megelőzhető a betegségek jelentős része és javítható az egészségi állapot (GOETZKE et al., 2014). A társadalmi értékváltás és a fogyasztói szemlélet megváltozása az élelmiszeripari szereplőket arra sarkallta, hogy olyan élelmiszereket fejlesszenek ki, s vigyenek piacra, melyek egészségvédő hatásokkal rendelkeznek, így fogyasztásuk megelőzheti a civilizációs népbetegségek kialakulását, illetve lassíthatja azok súlyosbodását. E termékeket a nemzetközi tudományos és szakmai körök ún. funkcionális élelmiszereknek nevezték el (SZAKÁLY, 2009). Az International Life Sciences Institute (ILSI; Nemzetközi Élettudományi Intézet, Brüsszel) nemzetközileg alkalmazott meghatározása alapján a funkcionális élelmiszerek kategóriája olyan élelmiszereket jelöl, melyek az alapvető táplálkozási hatásokon túlmenően bizonyítottan előnyös hatást gyakorolnak a szervezet müködésére, mely által jobb egészségi és jólléti állapot érhető el, vagy csökkenthető egyes kórképek kialakulásának kockázata (ASHWELL, 2002). Az Európai Bizottság az alábbi csoportokat különbözteti meg a funkcionális élelmiszereken belül: (a) természetes élelmiszer, mely mentes bármiféle technológiai vagy növénynemesítési eljárástól (pl. gyümölcs, zöldség); (b) élelmiszer hozzáadott speciális komponenssel (pl. gabona hozzáadott vitaminnal); (c) élelmiszer, amiből bizonyos komponenseket csökkentettek/kivontak (pl. zsírszegény vagy cukormentes joghurt); (d) élelmiszer, amiben bizonyos komponenseket módosítottak vagy helyettesítettek annak érdekében, hogy növeljék az egészségre gyakorolt pozitív hatását (pl. joghurt hozzáadott probiotikumokkal) (EUROPEAN COMMISSION, 2010). Mindezek alapján az élelmiszerek tulajdonképpen bármely kategóriájában kifejleszthetőek funkcionális készítmények, azonban az Európai Unió országainak funkcionális élelmiszerpiacait hagyományosan a probiotikus tejtermékek és étrend-kiegészítők dominálják jelenleg is (PEDRETTI, 2013).

\section{TörTÉNELMI hÁTTÉR -}

\section{HISTORICAL BACKROUND}

Az egészségre jótékony hatású tejtermékek tudatos fogyasztása jóval az időszámításunk kezdete előtti korokra nyúlik vissza. Az emberiség ugyanis már évezredekkel ezelőtt felismerte a fermentált tejtermékek jelentőségét az egészséges táplálkozásban. A legősibb korokba kalauzol el bennünket a Szentírás, melynek Ószövetségi részében, a Teremtés Könyvében található az a szövegrész, mely a hosszú életü Ábrahám tej- és vajfogyasztását írja le (Biblia, Genezis 18:8). Az ókori Mezopotámiában Kr.e. 2500ban készült ősi falfestéseken örökítették meg a sumérok eljárását a tej beoltására a fermentáció kiváltása céljából (FULLER, 1992). Hippokratész máig idézett bölcseletei az „Az vagy amit megeszel”, illetve „Gyógyszered legyen az ételed, s ételed legyen a gyógyszered”. Krédójának megfelelően az orvostudomány atyjaként számon tartott hellén polihisztor könyvei közül több is a táplálkozás kiemelt szerepére világít rá az egészség megtartásában és a betegségek leküzdésében egyaránt [Peri diaitész oxeón Az akut betegségek étrendjéról; Peri diaitész hügieinész - Az egészséges étrendről; Peri diaitész - Az étrendről (négy könyv); Peri hügrón khésziosz - Az italok használatáról; Peri trophész - A táplálékról (aforizmagyüjtemény)]. Ezekben számos helyen is ír a különféle tej és tejtermékek egészségvédő szerepéről. A görög iskolákat követő klasszikus római tudományok polihisztora, Plinius a Kr. e. 77-ben elkészült 'Naturalis Historiae' című enciklopédiájában részletesen írt az erjesztett tejtermékek javasolt 
fogyasztásáról különféle gyomor- és bélbetegségek esetén, mely írása még a Kr. u. IV. századi orvosi kézikönyveknek is alapjául szolgált (DEMETER, 2006).

A fermentált tejtermékek évezredeken keresztüli empirikus alapokon történő egészségvédő és terápiás használatát követően, 1907-ben Ilja Mecsnyikov alkotta meg a tejtermékekben előforduló jótékony hatású baktériumtörzsek modern alkalmazásának koncepcióját. Az orvosi Nobel-díjjal kitüntetett orosz biológus már évek óta tanulmányozta a vastagbél baktériumflórájának a betegségekben és időskori leromlásban betöltött káros szerepét, és meg volt győződve arról, hogy az emberek vastagbelének sebészi eltávolítása szükséges az egészségük fenntartása érdekében. Azonban a bolgár parasztok átlagosnál jóval hosszabb életének hátterében álló okok tanulmányozása során felfedezte egyes bélbaktériumok jótékony hatásait is. Így az 1907-ben született tanulmányában tudományos módszerekkel igazolta a Lactobacillust tartalmazó joghurt fogyasztásának szerepét az egészség megőrzésében és a hosszú életkor elérésében (METCHNIKOFF, 1907). A modern tudomány a latin pro és gö-

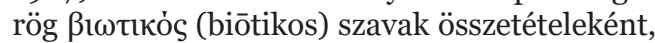
probiotikum (jelentése: az életért) néven jelöli ezeket a mikrobákat, melyek jótékony hatással vannak a szervezet egészségi állapotára. Ahhoz azonban, hogy pontosabb képet kaphassunk a tejtermékekkel bevitt probiotikumok egészségre gyakorolt hatásairól, érdemes áttekinteni az emberi bélflóra múködését.

\section{A BÉLFLÓRA JELLEMzói -}

\section{INTESTINAL MICROFLORA}

A vastagbél flórája egy igen összetett és dinamikus változást mutató mikrobaközösség, mely fontos szerepet játszik a szervezet anyagcseréjében, a tápcsatorna integritásának és védelmének fenntartásában, illetve részt vesz a patogén kórokozók elleni védekezésben és a szervezet immunrendszerének kialakulásában és optimális funkciójának fenntartásában is. Habár korábbi tanulmányok úgy becsülték, hogy e mikrobák teszik ki az emberi testet alkotó sejtek 90-95\%-át, az újabb vizsgálatok alapján helyesebb csak 50\% körüli arányról beszél- ni. Mindazonáltal figyelembe véve a bélflóra sokrétű és elengedhetetlen élettani funkcióit, számos szerző a testünk „külső” szervének nevezi azt (WACHA, 2012).

Az emberi vastagbél érdemi bakteriális kolonizációja a születést követően kezdődik meg, mikor az újszülött a szülőcsatornán áthaladva először az anyai baktérium flórával, Streptococcusokkal, Staphylococcusokkal és Enterobaktériumokkal találkozik, melyek az újszülött bélrendszerébe kerülve az oxigén felhasználásával ideális anaerob környezetet hoznak létre a Lactobacillusok és Bifidobacteriumok számára, melyek 1-2 héten belül stabilizálják az újszülött bélflórájának összetételét (FANARO et al., 2003). Később a táplálékkal együtt bekerülve egyre többféle baktérium jelenik meg a tápcsatornában, ezáltal az élet során a bélflórát az elfogyasztott ételek összetétele és minősége alapvetően befolyásolja. A felnőttek bélflórájában a Bacteroides, Bifidobacteria, Eubacteria és Peptostreptococcus genusok dominálnak, míg a kisebb számban jelen lévő organizmusok, úgymint Streptococcus és Lactobacillus genus, valamint az Enterococcus, Clostridium, és Bacillus genus a szubdomináns flóra részét képezik. A stabil flórát alkotó baktériumok mellett különböző exogén baktériumok, olyanok melyek képesek sértetlenül áthaladni a tápcsatornán, mikroflórát képezhetnek átmeneti jelleggel. Az optimális összetételü, egészséges bélflóra tagjai termelik azokat a metabolitokat (arginin, glutamin, rövidláncú zsírsavak) melyek a bélhámsejtek fő energiaforrásául szolgálnak. Szerepük van továbbá az emészthetetlen poliszacharidok lebontásában, a kalcium, a magnézium és a vas felszívódásában, illetve a szervezet számára létszükséges vitaminok (thiamin, folsav, pyridoxin, K vitamin) termelésében. A mikroflóra további fontos funkciója, hogy védelmi vonal szerepét tölti be a kórokozók széles skálájával (pl. Clostridium, Escherichia coli, Salmonella, Shigella, Pseudomonas, Candida albicans) szemben, megakadályozva azok kolonizációját a bélben (SALMINEN et al., 1995). Az egészséges bélflóra baktériumai a nyálkahártyához tapadva az epitélsejteken lévő receptorokon kompetícióba lépnek a patogén mikrobákkal, továbbá baktericid, vagy bakteriosztatikus fehérjéket termelhetnek a kórokozókkal szemben. Mindezek mellett az újabb 
tanulmányok rávilágítottak az elengedhetetlen szerepükre a szervezet immunrendszerének kialakulásában és megfelelő müködésében is (BÄCKHED et al., 2005). Figyelembe véve, hogy a bélflórát építő és károsító baktériumok is az élelmiszerekkel kerülnek be szervezetünkbe, kiemelt jelentőséggel bír a táplálkozás minősége, és a bevitt mikrobák jellemzői.

\section{A PROBIOTIKUMOK}

\section{ALKALMAZÁSA - APPLICATIONS OF Probiotics}

A FAO/WHO meghatározása szerint a probiotikumok olyan élő mikroorganizmusok, melyek megfelelő adagban a gazdaszervezet számára kedvező egészségügyi hatást fejtenek ki. A probiotikus mikrobák segítenek helyreállítani a normál bélflórát fertőzés, gyulladás vagy antibiotikum kezelést követően, részt vesznek a karcinogén metabolitok eltávolításában, továbbá szerepük van a vér koleszterinszintjének csökkentésében is (SANDERS, 2000). Az egyik leghangsúlyosabb funkciójuk azonban az immunrendszert támogató hatásuk, mely által fontos szerepet játszanak a szervezet általános ellenállóképességének fokozásában a fertőző ágensekkel, a daganatképződéssel és a különféle környezeti stresszhatásokkal szemben (CSIKI et al., 2010).

A leggyakrabban alkalmazott probiotikumok közé a Lactobacillusok, Bifidobacteriumok, Bacillus clausii, illetve a Saccharomyces boulardii élesztőgombák tartoznak, melyek jótékony hatását a betegségmegelőző szerepükön túlmenően több kórállapotban is bizonyították. Ide tartoznak a bakteriális és vírusos eredetü hasmenések, továbbá a széles spektrumú antibiotikumok mellett kialakuló diszbakteriózis, bélnyálkahártya károsodás és következményes hasmenés. A probiotikumok klinikai hatékonyságát számos más betegségben is vizsgálták, többek között diabetes mellitusban, elhízásban, időskori emésztési zavarokban, vastagbél karcinómában és gyulladásos bélbetegségekben is. Újabb kutatások arra is rámutattak, hogy probiotikumok tumor-ellenes hatásokkal rendelkezhetnek, fogyasztásuk gátolhatja a rák progresszióját, illetve növelheti a dagana- tok kezelésére használt immunterápiák hatékonyságát (PAPP-BATA et al., 2018a). Újabb vizsgálatok igazolták, hogy különböző probiotikumok egyidejü alkalmazása során jótékony hatásaik nem csupán összeadódnak, hanem jelentősen fel is erősíthetik egymást. A napjainkban gyártott készítmények (kapszulák, porok, savanyított tejtermékek, joghurtok stb.) zöme már komplex, több törzset tartalmazó készítmények.

A probiotikus élelmiszerek ipari előállítása során számos biztonsági és technológiai kritériumnak kell megvalósulnia. Az alkalmazott mikrobáknak képesnek kell lenniük a bélnyálkahártya kolonizálására, nem viselkedhetnek kórokozóként a gazdaszervezetben és nem adhatnak át antibiotikum-rezisztencia géneket más mikrobák számára. Mindezeken túlmenően a hozzáadott probiotikumok nem ronthatják le az élelmiszerek ízét és élvezeti értékét. A fogyasztás esetleges mellékhatásait tekintve ritkán puffadást írnak le, mely jelenséget sokszor egyértelműen nem lehet elkülöníteni a probiotikum fogyasztását szükségessé tevő emésztési zavarok tüneteitől, illetve más szedett gyógyszerek mellékhatásaitól. Fontos azonban figyelembe venni, hogy immunszuppresszióval járó kórképek és terápiák, ideértve a daganatok kemo- illetve sugárterápiáját, szívbelhártya-gyulladás, garatfertőzések és mütétet követően a szepszis veszélye miatt kerülendő a probiotikumok adása (SALMINEN et al., 2006). Lényeges továbbá, hogy tejcukorés lisztérzékenyeknél a laktóz- és gluténtartalmú probiotikumok hasmenéshez vezethetnek, míg a fehérjeallergiás betegeknél az anafilaxiás reakció kifejlődésének veszélye miatt nem javasolt a probiotikus tejtermékek alkalmazása (MARTÍN-MUÑOZ et al., 2012).

\section{A PROBIOTIKUS TEJTERMÉKEK PIACA - PROBIOTIC DAIRY PRODUCTS' MARKET}

A probiotikus élelmiszerek, étrend-kiegészítók és gyógyszerek iránti fogyasztói kereslet dinamikus növekedését jól mutatja, hogy amíg 2010-ben e termékek világpiaci értékesítése 21,6 milliárd USD volt, addig 2018-ra 49,4 mil- 
liárd USD-ra nőtt, mely az időközi gazdasági világválság ellenére nem csak hogy nem maradt el a 2013-ban 2018-ra prognosztizált 44,9 milliárd USD értékról (PEDRETTI, 2013), de meg is haladta azt. Az eddigi trendeknek megfelelően, a piaci előrejelzések alapján a probiotikumok globális piaca 2023-ra el fogja érni a 69,3 milliárd USD-t, elsősorban az ázsiai és dél-amerikai piaci bővülésből adódóan (MARKETS AND MARKETS, 2019). A jelenleg is zajló COVID-19 világjárvány azonban ezen felül várhatóan további robbanásszerű piaci bővüléshez vezet, ugyanis a fogyasztók világszerte keresik azokat az eszközöket, melyekkel megfelelően támogathatják az immunrendszerük működését, és az esetleges vírusfertőzés elleni válaszkészségüket.

A funkcionális élelmiszerek piacát tekintve Európában a különféle joghurtok és fermentált tejtermékek a leggyakoribb élő mikrobákat tartalmazó élelmiszeripari termékek (STANTON et al., 2001). Az USA-ban 2008-ban kirobbant gazdasági válság Európa irányába történő exportját követő gazdasági lassulás alapvetően befolyásolta régiónk piaci lehetőségeit, mely érintette a funkcionális termékek piacát is. Az elmúlt évek trendjeit tekintve hazánkban a vonatkozó tejtermékek fogyasztásának kezdeti emelkedését követően 2017-ben visszaesés, majd stagnálás volt megfigyelhető (1. táblázat).

Joghurt, kefir és tejföl fogyasztás alakulása Magyarországon (Yoghurt, Kefir and Sour Cream Consumption in Hungary)

\begin{tabular}{lccccc}
\hline \multicolumn{2}{l}{ Egy fóre jutó éves joghurt, kefir, tejöl fogyasztása (Annual consumption of yoghurt, kefir and sour } \\
cream per capita)
\end{tabular}

Forrás (Source): KSH (2019) alapján saját szerkesztés (Authors' own editing based on KSH (2O19))

A további piaci bővülés elérésének legfőbb feltétele a fogyasztók meggyőzése a probiotikus tejtermékek kipróbálására, illetve annak folyamatos használatára. A vásárlói bizalom kulcsfontosságú tényező, ugyanis mind táplálkozás-élettani, mind táplálkozásmarketing szempontból fontos hangsúlyozni, hogy a probiotikus élelmiszerkészítmények jótékony hatása a megfelelő bevitel (legalább 107-108 aktív mikroba/bevitel) esetén is csupán az alkalmazásuk időtartamára korlátozódik (ISHIBASHI és SHIMAMUR, 1993). Mindebből következik, hogy rendszeres és folyamatos fogyasztásuk szükséges ahhoz, hogy a szervezet számára egészségmegőrző hatással bírjanak. Ennek megfelelően nagy jelentősége van a probiotikus élelmiszerek megfelelő táplálkozásmarketingjének, melyben kiemelt szerepet kell kapnia a fogyasztói célcsoportok meghatározásának, a termékfejlesztésnek, a fogyasztói magatartás elemzésének, a márkázásnak és a marketingkommunikációnak.

Az élelmiszertechnológiai innovációk mellett a legnagyobb kihívást a megbízható, érthető és hiteles információk közvetítése jelenti a fogyasztók felé. Mivel a termékválasztást lényegében a fogyasztók szubjektív észlelése és preferenciája határozza meg, alapvetően fontos a megfelelően megtervezett és kivitelezett marketingkommunikáció. A funkcionális élelmiszerek esetén a fogyasztói észlelés anomáliái mögött gyakran a tudomány és a marketing eltérő filozófiai megközelítése állhat, melynek következtében kommunikációs rés képződik a tudományos érvek és a fogyasztói értelmezés között (KISS-törvény), melynek végeredménye a fogyasztói bizalomvesztés és a termék vásárlásának elutasítása lehet (SZAKÁLY, 2011). A probiotikus hatású tejtermékek esetében azonban a táplálkozásmarketing modelljei hatékonyan épülhetnek kifejezetten a termékek táplálkozás-élettani előnyeire, mivel a fogyasztók többsége éppen a tejtermékeket tekintik - a zöldség- és gyümölcsfélék mellett - a legegészségesebb élelmiszercsoportnak (SZAKÁLY et al., 2006). Mindezekből kifolyólag a probiotikus tejtermékeknél a kutatás-fejlesztés és innováció tölt be kulcsfontosságú pozíciót a tejtermékekre adaptált táplálkozásmarketing integrált modelljében (1. ábra), azzal a kiegészítéssel, hogy a vásárlói tudatformálás és a fogyasztók ismereteinek folyamatos bővítése továbbra is kiemelt jelentőségú. 


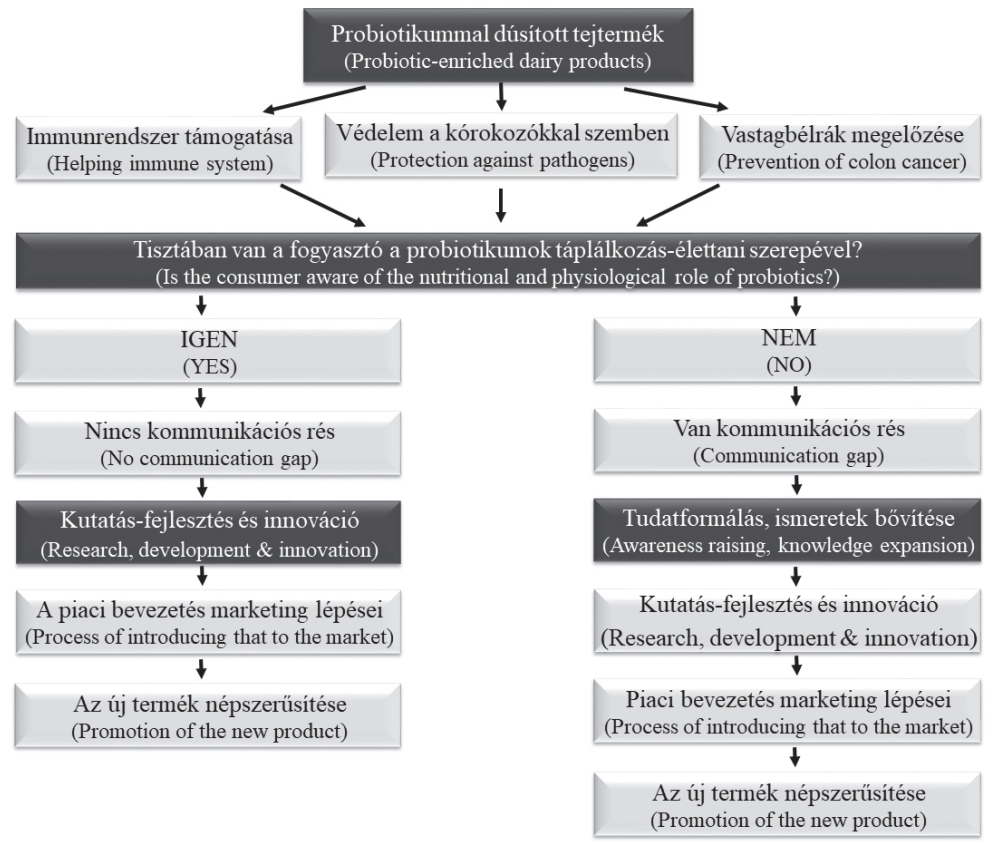

\section{1. ÁBRA}

A táplálkozásmarketing modell elemei probiotikummal dúsított tejtermékeknél (The Nutrition Marketing Model of Probiotic-Enriched Dairy Products)

Forrás (Source): Saját szerkesztés (Authors'own compilation)

\section{A JöVố KÉRDÉSEI - QUESTIONS OF THE FUTURE}

Látható, hogy a probiotikumok iránti fogyasztói kereslet világszerte dinamikus növekedést mutat, azonban a tendenciák megértéséhez fontos figyelembe venni azt, hogy a probiotikus termékek nem alkotnak homogén csoportot, ugyanis egyaránt lefedik a probiotikumot tartalmazó élelmiszereket, étrend-kiegészítőket, valamint a probiotikus gyógyszereket is. Tehát a probiotikumok esetében az élelmiszeripar mellett a gyógyszeripar is felfigyelt a változó fogyasztói szokások által nyújtott új lehetőségekre, így a globális piacon létrejött egy „szürke zóna”, melyben az átfedő érdekek miatt versenyhelyzet alakult ki az élelmiszer- és gyógyszeripari szereplók között (PAPP-BATA et al., 2014). A piaci adatok alapján a probiotikumok globális kereskedelme 2015-ben 41 milliárd USA dollár volt, melynek $75 \%$-át a probiotikus joghurtok, 16\%-át az egyéb élelmiszeripari probiotikus termékek és 9\%-át a probiotikus gyógyszerek tették ki. A joghurtok kiemelkedő piaci részesedése mögött az áll, hogy a fogyasztók zöme rendszeresen eszik joghurtot, és egyre több márka rendelkezik tanúsítvánnyal az aktív baktériumkultúrákat illetően, így biztosítva a termékeik probiotikumként való piaci pozícionálását. Ennek ellenére a probiotikumok legújabb innovációinak nagy része a gyógyszerek gyártásából származik, melyek világpiaci kereskedelme már közel 4 milliárd dollárt tett ki 2015-ben és a 2020-ról készülő jelentésekben várhatóan 37 százalékos növekedés lesz megfigyelhetőn (FELDMAN, 2016). Ennek hátterében egyrészt a nem-fehér rasszokba tartozó fogyasztók széles körében megfigyelhető laktózintolerancia állhat, másrészt pedig az a tény, hogy a XXI. század kezdete óta egyre több klinikai/orvostudományi kutatást végeznek a probiotikus mikrobák egészségügyi hatásmechanizmusaival kapcsolatban, mely hagyományosan a gyógyszeripari szereplők területe. A megfigyelt trendek tehát arra utalnak, hogy a porok és kapszulák formájában alkalmazott 
probiotikumok globális szinten a jövőben jobban előtérbe fognak kerülni, mégpedig vélhetően a hagyományos probiotikus tejtermékek rovására.

A nyugati és távol-keleti társadalmak drasztikus elöregedése is új helyzetet teremthet a probiotikus élelmiszereket gyártók számára. Tekintve, hogy számos országban jelenleg az 50-65 év közötti fogyasztók alkotják a lakosság legnagyobb létszámú, s egyben pénzügyileg a legtehetősebb részét, a következő két évtizedben az idősebb fogyasztók fogják képezni az európai, az észak-amerikai és a távol-keleti kereskedelem fő hajtóerejét. Az EU országaiban a jelenleg 50-65 év közötti fogyasztók általában véve nagyobb hangsúlyt helyeznek az egészségükre és a rutin orvosi vizsgálatokra, mint a fiatalabb nemzedékek, és sokuk aktívan keres olyan termékeket és szolgáltatásokat, amelyek hozzájárulnak az egészséges életmódhoz (PAPP-BATA et al., 2018a). Mindezek tükrében 10-15 év múlva az időskorú lakosság vélhetően az egyik legjelentősebb fogyasztói tényezőnek fog számítani a probiotikumok kereskedelmében, és vélhetően ennek megfelelően fog alakulni a gyógyszergyártó és élelmiszer-gyártó cégek innovációs és termékfejlesztési stratégiája is.

\section{KöVETKEZTETÉSEK - CONCLUSIONS}

Habár az emberiség évezredek óta alkalmazza a fermentált tejtermékeket az egészség fenntartása céljából, a bélflóra baktérium összetételének megváltoztatásának a tudományos alapokon nyugvó modern módszerei csak az elmúlt évtizedekben fejlődtek ki. A hatékony probiotikus termékek kifejlesztéséhez elengedhetetlenek a tudományos és technológiai innovációk, melyek bővíthetik az egészségre előnyös mikrobákat tartalmazó élelmiszerek körét. Az elmúlt 10-15 évben számos táplálkozás-élettani klinikai kutatás zajlott, melyek eredményeit elsősorban a gyógyszeripar használta fel, azonban ezek az eredmények potenciális alapul szolgálhatnak az élelmiszeripar további fejlesztéseihez is. Míg Távol-Keleten a fogyasztók számára a funkcionális élelmiszerek élvezeti értékénél jóval fontosabb azok egész- ségre gyakorolt hatása, addig Európában és Észak-Amerikában a fogyasztók kevésbé hajlamosak kompromisszumot kötni a termékek ízvilágának rovására (SIRÓ et al., 2008), mely az élelmiszeripar számára a versenyhelyzetben előnyös hátteret jelenthet.

A már kifejlesztett probiotikus termékek piaci sikerében viszont a megfelelő marketingstratégiának és -kommunikációnak van kulcsszerepe. A személyes motivációk, az egészségtudatos életmód és a bizalomteljes fogyasztói attitűd kialakításában fontos szerep jut a megfelelő, hiteles tájékoztatásnak (PAPP-BATA et al., 2018b). Erre megoldást nyújthat, ha a probiotikus élelmiszereket gyártó, illetve forgalmazó cégek egészségügyi szakemberek bevonásával határozzák meg marketingstratégiájukat, továbbá az egészséges táplálkozást népszerúsítő promóciós programjaikba a társadalom számára hiteles orvosokat és dietetikusokat is bevonnak.

\section{8. ÖSSZFOGLALÁS - SUMMARY}

Az étrend és egészség közötti kapcsolat tudományos igazolása, valamint az egészségtudatos döntéseket hozó fogyasztók egyre növekvő aránya társadalmi értékváltáshoz és az egészségvédő élelmiszerek iránti fokozott fogyasztói igényhez vezetett. A probiotikus termékek, különösen az aktív kultúrákat tartalmazó tejtermékek erőteljesen növekvő szegmenst képviselnek a funkcionális élelmiszerek piacán. Habár az emberiség már évezredekkel ezelőtt felismerte a fermentált tejtermékek jelentőségét az egészséges táplálkozásban, a bélflóra baktérium összetételének megváltoztatásának a tudományos alapokon nyugvó modern módszerei csak az elmúlt évtizedekben fejlődtek ki. A bélflóra probiotikumokkal történő megerősítése kulcsfontosságú szerepet játszik a kiegyensúlyozott immunfunkciókban, növeli a kórokozókkal szembeni ellenállást, javítja az emésztőrendszer funkcióit és potenciálisan elősegíti a rákkeltő anyagok eltávolítását a tápcsatornából.

A probiotikus termékek iránti fogyasztói kereslet nagymértékü növekedést mutat, míg 2010-ben a világpiaci értékesítésük 21,6 milliárd USD volt, 2018-ra 49,4 milliárd USD-ra 
nőtt. A probiotikumok globális kereskedelmének 75\%-át a probiotikus joghurtok, 16\%-át az egyéb élelmiszeripari probiotikus termékek és 9\%-át a probiotikus gyógyszerek teszik ki, azonban a jelenlegi trendek alapján a gyógyszeripari termékek szerepe fokozatosan növekedni fog a jövőben, vélhetően a hagyományos probiotikus tejtermékek rovására. Továbbá tekintettel arra, hogy 10-15 év múlva az időskorú lakosság vélhetően az egyik legjelentősebb fogyasztói tényezőnek fog számítani a nyugati és távol-keleti piacokon a probiotikum kereskedelmében, ennek megfelelően szükségessé válhat átalakítani és újrapozícionálni az innovációs és termékfejlesztési stratégiát is. A probiotikus tejtermékek piaci sikerének biztosításában és jövőbeni további növelésében a megfelelő marketingstratégiának és -kommunikációnak is kulcsszerepe van. A személyes motivációk, az egészségtudatos életmód és a bizalomteljes fogyasztói attitűd kialakításában fontos szerepe van a megbízható és hiteles tájékoztatásnak.

\section{KöSZÖNETNYILVÁNÍTÁS -}

\section{ACKNOWLEDGEMENTS}

A cikk elkészítését a GINOP-2.3.2-152016-00062 számú projekt támogatta. A projekt az Európai Unió támogatásával, az Európai Regionális Fejlesztési Alap társfinanszírozásával valósult meg.

\section{IRODALOMJEGYZÉK - REFERENCES}

Ashwell, M.: Concepts of Functional Foods. ILSI Press, Brussels, 2002.

Bäckhed, F. - Ley, R. E. - Sonnenburg, J. L. - Peterson, D. A. - Gordon, J. I.: Host-Bacterial Mutualism in the Human Intestine. Science. 2005. 307 (5717) 1915-1920. DOI: https://doi.org/10.1126/ science.1104816.

Csiki, Z. - Zeher, M. - Papp, G. - András, Cs. - Takáts, A. - Csiki, E.: Pre-, proés szibiotikumok szerepe, kedvező élettani hatásaik. Metabolizmus. 2010. 8 (5) 288292.
Demeter, P.: A probiotikumok alkalmazásának lehetőségei emésztőszervi betegségekben. LAM. 2006. 16 (1) 41-47.

European Commission: Functional Foods. Publications Office of the European Union, Luxembourg, 2010.

Fanaro, S. - Chierici, R. - Guerrini, P. - Vigi, V.: Intestinal Microflora in Early Infancy: Composition and Development. Acta Paediatrica Suppl. 2003. 91 (441) 48-55. DOI: https://doi. org/10.1111/j.1651-2227.2003.tboo646.x.

Feldman, M.: The New Market Profile of Probiotics Consumption. In: Natural Products Insider. 2016.09.22. URL: https://www.naturalproductsinsider. com/digestive-health/new-marketprofile-probiotics-consumption (Letöltés dátuma: 2021.01.06.)

Fuller, R.: History and Development of Probiotics. In Probiotics, Springer, Netherlands, 1992. 1-8.

Goetzke, B. - Nitzko, S. - Spiller, A.: Consumption of Organic and Functional Food. A Matter of Well-Being and Health? Appetite. 2014. 77 96-105. DOI: https:// doi.org/10.1016/j.appet.2014.02.012.

Ishibashi, N. - Shimamur, S.: Bifidobakteria: Research and Development in Japan. Food Technology. 1993. 47 (6) 126-135.

Központi Statisztikai Hivatal: Az egy före jutó éves élelmiszer-fogyasztás mennyisége jövedelmi tizedek (decilisek) szerint. URL: https://www.ksh.hu/docs/hun/xstadat/ xstadat_eves/i_zhco23a.html (Letöltés dátuma: 2021.01.05.)

Markets and Markets: Probiotics Market by Application (Functional Food \& Beverages [Dairy Products, Non-dairy Beverages, Infant Formula, Cereals], Dietary Supplements, Feed), Ingredient (Bacteria, Yeast), Form (Dry, Liquid), End User, and Region-Global Forecast to 2023. 2019. URL: https://www.marketsandmarkets. com/Market-Reports/probiotic-marketadvanced-technologies-and-globalmarket-69.html (Letöltés dátuma: 2021.01.09.) 
Martín-Muñoz, M. F. - Fortuni, M. Caminoa, M.: Anaphylactic Reaction to Probiotics. Cow's Milk and Hen's Egg Allergens in Probiotic Compounds. Pediatric Allergy and Immunology. 2012. 23 (8) 778-784. DOI: https://doi. org/10.1111/j.1399-3038.2012.01338.x.

Metchnikoff, E.: Lactic Acid As Inhibiting Intestinal Putrefaction. The Prolongation of Life: Optimistic Studies. (Szerk.: Chalmers, M. P.). Heinemann, London, 1907. 161-183.

Mendis, S. - Puska, P. - Norrving, B.: Global Atlas on Cardiovascular Disease Prevention And Control. World Health Organization, Geneva, 2011.

Papp-Bata, Á. - Csiki, Z. - Szakály, Z.: A funkcionális élelmiszerek egészségügyi és gazdasági jelentősége. Magyar Gasztroenterológia. 2014. (Suppl 2) 1-5.

Papp-Bata, Á. - Mile, M. - Szakály, Z. Csiki, Z.: A probiotikumok alkalmazása időskorban - egészségügyi megfontolások és piaci helyzetkép. Idősgyógyászat. 2018a. 3 (2) 63-67.

Papp-Bata, Á. - Csiki, Z. - Szakály, Z.: Az egészségvédő élelmiszerekkel kapcsolatos fogyasztói magatartás - A hiteles tájékoztatás szerepe. Orvosi Hetilap. 2018b. 159 (30) 1221-1225. DOI: https:// doi.org/10.1556/650.2018.31121.

Pedretti, S.: Probiotic Market: Up or Down? Nutrafoods. 2013. 12 N18-N19.

Salminen, S. - Isolauri, E. - Onnela, T.: Gut Flora in Normal and Disordered States. Chemotherapy. 1995. 41 (1 Suppl) $5 \mathrm{~S}-15 \mathrm{~S}$. DOI: https://doi.org/10.1159/ooo239391.

Salminen, M. K. - Rautelin, H. - Tynkkynen, S. - Poussa, T. - Saxelin, M. - Valtonen, V. Järvinen, A.: Lactobacillus Bacteremia, Species Identification, and Antimicrobial Susceptibility of 85 Blood Isolates. Clinical Infectious Diseases. 2006. 42 (5) e35-44. DOI: https://doi.org/10.1086/500214.
Sanders, M. E.: Considerations for Use of Probiotic Bacteria to Modulate Human Health. The Journal of Nutrition. 2000. 130 (2S Suppl) 384S-39oS. DOI: https:// doi.org/10.1093/jn/130.2.384S.

Siró, I. - Kápolna, E. - Kápolna, B. Lugasi, A.: Functional Food. Product Development, Marketing and Consumer Acceptance - A Review. Appetite. 2008. 51 (3) 456-467. DOI: https://doi. org/10.1016/j.appet.2008.05.060.

Stanton, C. - Gardiner, G. - Meehan, H. - Collins, K. - Fitzgerald, G. Lynch, P. B. - Ross, R. P.: Market Potential for Probiotics. The American Journal of Clinical Nutrition. 2001. 73 (2 Suppl) $476 \mathrm{~S}-783 \mathrm{~S}$.

Szakály, Z.: Egészségmagatartás és funkcionális élelmiszerek: hogyan vélekednek a hazai fogyasztók? Élelmiszer, Táplálkozás és Marketing. 2009. 6 9-18.

Szakály, Z. - Szigeti, O. - Szente, V. - Sándor, J.: Az egészségtudatos fogyasztói magatartás elemzése a light termékek piacán. Kutatói Jelentés. Kaposvári Egyetem GTK - Market and Fact Piackutató és Marketing Tanácsadó Intézet, Kaposvár, 2006. 1-80.

Szakály, Z.: Táplálkozásmarketing. Mezőgazda Kiadó, Budapest, 2011.

Wacha, J.: A bélflóra szerepe az anyagcsereegyensúly fenntartásában. Metabolizmus. 2012. 10 (5) 336-340. 